\title{
Growth and gonad development of the tropical black-lip pearl oyster, Pinctada margaritifera (L.), in the Gambier archipelago (French Polynesia)
}

\author{
Gilles Le Moullac ${ }^{1,{ }^{*}}$, Jérôme Tiapari ${ }^{1}$, Hinano Teissier ${ }^{1}$, Elodie Martinez ${ }^{2}$ and Jean-Claude Cochard ${ }^{3}$ \\ ${ }^{1}$ Laboratoire Domestication de l'Huître perlière, Département Lagon Environnement Aquaculture Durable en \\ Polynésie Française, Centre du Pacifique, IFREMER, BP 7004, 98719 Taravao, French Polynesia \\ ${ }^{2}$ Laboratoire d'Océanographie de Villefranche, Observatoire Océanologique de Villefranche, Quai de La Darse, \\ BP 8, 06238 Villefranche sur Mer Cedex, France \\ ${ }^{3}$ Département Environnement Littoral et Ressources aquacoles, Centre de Brest, IFREMER, BP 70, 29280 \\ Plouzané, France
}

*: Corresponding author : G. Le Moullac : tel : + 6895460 06, fax : + 6895460 99, email address :

Gilles.Le.Moullac@ifremer.fr

\begin{abstract}
:
The growth and reproductive cycle of cultured black-lipped pearl oysters, Pinctada margaritifera (L.), were studied in the Gambier Islands $\left(134^{\circ} 52^{\prime} \mathrm{W}, 2^{\circ} 07^{\prime} \mathrm{S}\right)$ from September 2002 to August 2003. Temperatures were recorded throughout the year, revealing seasonal temperature variations between 22.3 and $27.8^{\circ} \mathrm{C}$. The mean annual chlorophyll a value, as computed from satellite data, was $0.188 \pm 0.075 \mu \mathrm{g} \mathrm{L}^{-1}$. To study growth and reproduction, 720 two-year-old individuals were ear hung on long-lines suspended at a depth of $7 \mathrm{~m}$. Samples were taken twice a month to obtain the following measurements: shell height; wet weight of flesh and total oyster; dry weight of adductor muscle, mantle and visceral mass; and glycogen content. Gonad development was also studied by histology on parallel samples. Growth was relatively fast during the first 6 months of the study: average shell height increased from $89.1 \pm 9.1$ to $119.7 \pm 10.8 \mathrm{~mm}$ and total weight from $93.4 \pm 24.5$ to $155.1 \pm 33.6 \mathrm{~g}$, between September and the end of March. Subsequently, from April to August, no significant growth was observed for shell and flesh, while the muscle weight decreased significantly. Condition index $(\mathrm{Cl})$, defined as the ratio of wet weight of the visceral mass to shell weight, and histological changes in the gonad revealed 3 significant reproductive events of different intensities. The analysis of correlations revealed a specific effect of the chlorophyll a concentration on the growth of shell and soma, and one of the temperature on tissue glycogen content. This study also showed also that $\mathrm{Cl}$ could be an efficient indicator of reproductive events in pearl oyster. It thus appears that the development of gonads goes on throughout the year in the Gambier Islands, without any detectable phase of sexual rest.
\end{abstract}

Keywords: Pearl oyster - Pinctada margaritifera - Growth - Reproduction - Temperature Chlorophyll - Seasonality - Gambier archipelago 


\section{Introduction}

46 Pearl oyster farming in French Polynesia is spread over a large geographical area. Environmental conditions vary between islands in this part of the South Pacific, particularly due to differences in their latitudinal position. Seasonal cycles are more marked in southern Polynesia than further north. The annual reproductive cycle of Pinctada margaritifera was studied in the Takapoto atoll of the northern Tuamotu Islands, showing that reproduction occurs throughout the year due to a high average temperature with low seasonal variation (Thielley 1993, Pouvreau et al. 2000a). Adequate data on the marine environment and the reproduction of pearl oysters are, however, not yet available for other islands with pearl oyster farming. The largest thermal amplitude in French Polynesia (Salvat et al. 2008) is observed in the Gambier Islands (134 $\left.52^{\prime} \mathrm{W}, 2^{\circ} 07^{\prime} \mathrm{S}\right)$. Although reproduction of P. margaritifera still occurs in these islands, its reproductive cycle has not yet been described.

In the southern part of its distribution (Australia), the reproductive cycle of Pinctada albina has been observed to be modulated by seasonal temperature variations (O'Connor 2002). The reproductive cycle of the pearl oyster Pinctada mazatlanica is also affected by seasonal variations in temperature in Baja California (Saucedo et al. 2002), where a period of intense sexual activity is observed in September when water temperature is high. Temperature changes due to El Nino and La Nina events have also been reported to affect the reproductive cycle of P. mazatlanica (Garcia-Cuellar et al. 2004).

The trophic environment is also known to act on the reproductive status of $P$. margaritifera (Pouvreau, et al. 2000b). In French Polynesia, due to low chlorophyll $a$ concentrations, the trophic environment is considered oligotrophic. Data on phytoplanktonic pigments have been obtained in the Takapoto atoll in northern Tuamotu (southern hemisphere), where concentration in chlorophyll $a$ ranged between 0.05 and $0.46 \mu \mathrm{g} \cdot \mathrm{L}^{-1}$ (Delesalle et al. 2001). 
Very little information on these parameters has been collected for the southern islands (Gambier Islands).

The objective of the present study was to examine the effect of the annual cycle of temperature and chlorophyll $a$ concentration on the reproductive cycle of $P$. margaritifera, to determine whether local environmental conditions in the Gambier Islands induce any marked seasonality in the reproductive cycle of this tropical pearl oyster species.

\section{Material and methods.}

\section{Gambier Islands}

Pearl culture has developed in several sites in the Gambier Islands (134 $52^{\prime} \mathrm{W} \& 23^{\circ} 07^{\prime} \mathrm{S}$ ), an Archipelago located in southeast French Polynesia (South Pacific).

\section{Environmental data}

Temperature was recorded hourly in situ using an automatic sensor (TidbiT temp LoggerOnset $^{\circledR}$ ). Chlorophyll $a$ concentration ( Chl a) data were derived from radiometric ocean colour provided by the Sea viewing Wide Field of view Sensor (SeaWiFS) onboard the

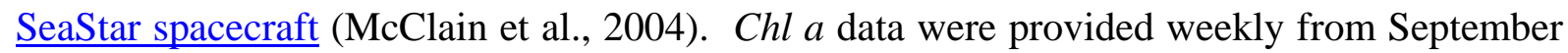
2002 to August 2003.

\section{Sampling}

Growth and reproduction of $P$. margaritifera were studied in pearl oysters reared in the

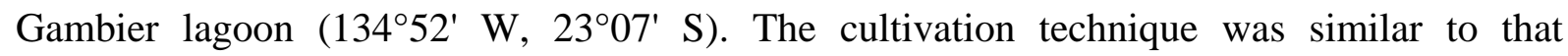
commonly used in commercial farms. Suspended long-lines were immersed at a depth of $7 \mathrm{~m}$ and pearl oysters were 'ear hung' on downlines in groups of ten. The reproductive cycle was studied over a year (from September 2002 to August 2003) by systematic sampling of 30 randomly selected individuals every 15 days. These pearl oysters were collected, cleaned of fouling organisms and sent by air to the Ifremer laboratory on Tahiti Island. 
94 For all specimens $(n=720)$, total weight and height of the shell were measured prior to dissection, weighing, sexing and histology. Sex was determined by rapid microscopic observation of fresh gonad smears. Glycogen content was then measured on 5 dried oysters for each sampling and the visceral mass of 15 other oysters was placed in Davidson's fixative for gonad histology.

Total wet flesh weights were obtained after 15 min of draining. After flesh dissection, the same operation was conducted separately on adductor muscle, gills + mantle and the visceral mass (gonad + digestive gland). Condition index (CI) was computed as the ratio of visceral mass weight to shell weight.

\section{Glycogen measurement}

104 Dry tissues of oyster were powdered and a 10-mg sample was then homogenized in $1 \mathrm{ml}$ of 105 de-ionized water. Changes in the glycogen composition of tissue over the year were 106 quantified using the phenol-sulphuric acid method of Dubois et al. (1956).

\section{Histology}

108 After dissection, gonadal tissue samples were placed in Davidson's fixative for five days,

109 after which they were preserved in $70 \%$ ethanol. Samples were then dehydrated through a 110 graded ethanol series, embedded in paraffin, sectioned at 3-4 $\mathrm{mm}$ on a rotary microtome, 111 stained with Giemsa dye and, finally, mounted on microscope slides. Sections were made in 112 the gonad area, between the proximal end of the gut loop and the base of the foot. Slide 113 preparations were examined with a light microscope to scan the entire gonadal area and assess 114 follicle stages. Reproductive stages of gonad development are based on the description by 115 Pouvreau et al. (2000a) shown in table 1. 
118 The growth parameters shell height, total weight, flesh and tissue weights and glycogen content in dried tissue are presented on the figures, with vertical bars representing the $95 \%$ confidence intervals. Correlations between environmental and physiological variables were

121 tested using the critical value table for Pearson's correlation coefficient at the $5 \%$ alpha level 122 and $108 \mathrm{df}$. The null hypothesis was rejected when $\mathrm{r}<0.195$.

\section{Results}

\section{Environmental data}

125 Water temperature gradually increased from the end of September up to a peak in March and 126 then declined to its lowest value in August. Mean annual water temperature was $25.42 \pm 1.75$ ${ }^{\circ} \mathrm{C}$, with a minimum of $22.3^{\circ} \mathrm{C}$ and a maximum of $27.8^{\circ} \mathrm{C}$ (Fig. 1a). The annual mean value

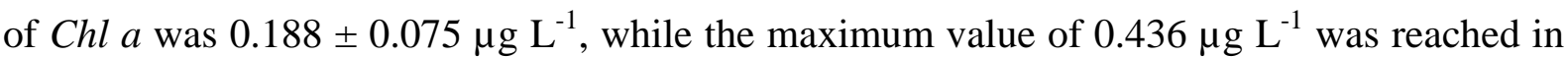
August 2003 (Fig. 1b). The gaps in the data are due to cloud cover.

\section{Pearl oyster growth}

Shell height and total weight increased regularly over the sampling period (Fig. 2a, 2b). The growth rates in terms of shell height and total weight were $87.40 \mu \mathrm{m} . \mathrm{d}^{-1}$ and 176.1 g.d $^{-1}$, respectively. From September 2002 to February 2003, flesh dry weight remained stable (Fig. 2c). A rapid increase then occurred from February 2003 to mid March 2003, followed by a

135 period during which mean flesh dry weight stabilised once more. Muscle dry weight showed 136 large variations over the year, with the highest value in mid-March (Fig. 3). Changes in 137 weight of the visceral mass were recorded twice, in mid-April and mid-August. (Fig. 3).

\section{Gametogenic cycle}

139 The condition index (CI) showed three significant decreases, the first in December, the second 140 in March and the third in June, while two non-significant changes of CI occurred in May and 
141 August (Fig. 4). Three significant increases of CI were recorded during this study; the first

142 time was in October, one month before the first significant decrease, the second time was in

143 April, just after the second significant decrease, and the third in July, just after the third 144 significant decrease (Fig. 4).

145 The temporal distribution of maturity stages over the year is shown in Figure 5. The three 146 significant CI decreases coincided with increases in the frequency of inactive (0) and early 147 gametogenic (1) stages, and the decrease in frequency of stages 2 to 5 , thus meaning that three 148 significant spawning events had occurred. The first spawning event in December was 149 smallest, since the frequency of the stage 0 and 1 was low. The spawning event in March 150 affected $>70 \%$ of oysters, since these were found to be at stage 1 of the maturity index, 151 while in May and June, spawning only affected $>30 \%$. In August, the non-significant 152 decrease of CI coincided with a $7 \%$ frequency of stage 1.

\section{Sex ratio}

154 The sex of all individuals was determined during this study. Figure 6a illustrates the change in 155 of this protandrous alternate hermaphrodite sex ratio over the year, while figure $6 \mathrm{~b}$ represents 156 the change in sex ratio according to the size of individuals. On average, $7 \%$ of individuals 157 were female, the highest value being $14 \%$. Only animals larger than $80 \mathrm{~mm}$ were female. The 158 proportion of females increased up to $22 \%$ for individuals larger then $140 \mathrm{~mm}$.

\section{Glycogen content}

160 Glycogen content in muscles significantly increased to $200 \mathrm{mg}$. $\mathrm{g}^{-1}$ between February and 161 May. In February, glycogen content increased significantly in the mantle, while it remained 162 unchanged in the visceral mass (Fig. 7). 


\section{Regression analysis}

164 Growth parameters (shell, flesh and tissue) were positively (p $<0.05$ ) correlated with Chl $a$

165 (Table 2). Glycogen content in VM and gill-mantle were negatively with Chl $a$, but glycogen

166 content in all tissues was positively correlated with water temperature (Table 2). Data related

167 to reproductive processes (CI) were not correlated with either chlorophyll or water

168 temperature (Table 2).

\section{Discussion}

\section{Environmental data}

171

172

173

174

175

176

177

178

179

180

181

182

183

184

185

186

187

Temperature recordings during this study (2002-2003) revealed an annual thermal amplitude $\left(6{ }^{\circ} \mathrm{C}\right)$ that was smaller than the one observed in 1998-1999 $\left(8^{\circ} \mathrm{C}\right)$ during the strong El NiñoLa Niña events. In comparison, the thermal amplitudes observed in the atolls of northern French Polynesia were $2{ }^{\circ} \mathrm{C}$ in 1990-1991 (Buestel and Pouvreau, 2000) and $4{ }^{\circ} \mathrm{C}$ in 1998 1999 (Pouvreau, 1999). Radiometric ocean colour derived from satellite observations was extracted for the eastern part of the Gambier archipelago in 2002 and 2003. Two difficulties arose. One was due to cloud cover, which interrupted the continuity of the time series. The second was related to the fact that ocean color is derived from radiance leaving the water, which may be influenced by water depth and bottom albedo (Maritorena et al., 1994). Interpretation of Chl $a$ variability must therefore to be considered with caution. However, the annual mean $\left(0.19 \mu \mathrm{g} . \mathrm{L}^{-1}\right)$ and amplitude range of Chl $a$ reported here are in agreement with values and seasonal patterns reported in several atolls in French Polynesia from in situ measurements (Charpy 1996; Intes et al. 1990). When considering the Chl $a$ time series extended to the beginning of 2002 (data not shown), the maximum value of Chl $a$ that we report here in August appears to be related to the Chl $a$ seasonal cycle. This Chl $a$ maximum in austral winter is also a typical seasonal pattern of Chl $a$ in Polynesian lagoons (Charpy 1996; Charpy et al, 2009). The large variations of Chl $a$ recorded during this study are also 
consistent with those measured in water samples from another Polynesian lagoon, Takapoto (Buestel and Pouvreau, 2000). These previous authors attributed this high variability to local meteorology (wind and precipitation), which had short-term, and night/day rhythms affecting some parameters (temperature and chlorophyll $a$ ).

\section{Growth}

Growth rate of pearl oysters seemed to be faster during the first six months of this study since the shell height and the total weight increased by $25 \mathrm{~mm}$ and $63 \mathrm{~g}$, respectively, in this period. No further significant changes in growth were then observed from April to August. In the size class considered (2-year-old oysters), shell growth was equivalent to that of oysters studied by Buestel and Pouvreau (1994) in Takapoto, where shell growth was found to be $30 \mathrm{~mm}$ over a whole year. Shell growth dynamics of pearl oysters observed in the present work were similar to those found in a study conducted in 1998-1999 in the Gambier Islands (Pouvreau and Prasil 2001).

Our results showed that pearl oyster growth in the Gambier Islands was correlated with Chl $a$ resources, which correspond to food supply, but not with temperature. The comparison of $P$. margaritifera growth between oysters reared in Gambier (this study; Pouvreau and Prasil 2001) and those reared in Pioneer Bay, north Queensland (18³7’ S, $146^{\circ} 30^{\prime}$ E), Australia (Yukihira et al. 2006), reveals a similar annual growth pattern. The two sites have similar temperatures, and a similar conclusion was drawn: that temperature had no significant effect on growth rates of $P$. margaritifera over the annual cycle.

Somatic growth pattern showed two phases. From September 2002 to February 2003, the flesh dry weight did not change significantly, but in March 2003 it doubled. Flesh dry weight then remained stable until August 2003. This change was mainly due to muscle increase, with visceral mass and mantle accounting for less. This growth event coincided with the maximum 
temperature observed during the study, but the examination of correlations only indicated a

213 significant relationship with chlorophyll $a$.

215 Pearl oyster reproduction was studied by Thielley (1993), and the reproductive cycle was 216 described by Pouvreau et al. (2000a) in the Takapoto atoll, northern Tuamotu. These authors 217 showed that, in a fairly stable tropical environment, $P$. margaritifera is a multiple spawner 218 with an opportunistic reproductive strategy that allows investment of any surplus energy into 219 gamete production throughout the year. CI variations in the present study were related to 220 quantitative losses of weight caused by gamete releases, while the histological analysis 221 revealed a degree of synchronicity within the population. Three spawning periods were 222 characterized by significant decreases of CI; these occurred in December 2002, March 2003 223 and June 2003. The decreases of CI corresponded precisely to periods of gamete release, as 224 confirmed by histological examination of gonadic stages. The first gamete emissions can be 225 regarded as resulting from the accumulation of gametes during winter. The second spawning, which occurred when temperature was maximal, involved most of the oysters since 227 histological analysis showed that $80 \%$ of them were at stage 1 or 2 . This spawning was 228 followed by rematuration. A third spawning occurred in June, when the temperature 229 descended below $24^{\circ} \mathrm{C}$, as shown by a significant decrease in CI and the stages shown in the 230 histological analysis. After this event, however, 30-40\% of individuals remained at 231 histological stage 1 of maturity and a similar proportion remained at stage 2 until the 232 beginning of August. At the end of August, a non-significant decrease in CI occurred when 7 $233 \%$ of the pearl oysters were at histological stage 1 ; these observations could indicate a 234 spawning event, despite the fact the temperature reached $22^{\circ} \mathrm{C}$.

235 Histology validated the interest of CI as spawning indicator for the pearl oyster. Spawnings 
values were 0.084, 0.070 and 0.076 respectively in December, March and June. This study

238 has shown that CI was not correlated with temperature and did not offer any new evidence to

239 support the hypothesis that spawnings were influenced by temperature. The greatest variations

240 in CI corresponded to the spawning in December, when temperature increased up to $25^{\circ} \mathrm{C}$;

241 the one in March, when the temperature was maximal $\left(28^{\circ} \mathrm{C}\right)$; and the one in June, when the 242 temperature decreased below $24{ }^{\circ} \mathrm{C}$.

\section{Sex ratio}

244 The proportion of females (7 \%) did not differ from the observations made by Pouvreau et al. 245 (2000a) in Takapoto. Indeed, for the age/size class considered here (2-year-old oysters, 100$246110 \mathrm{~mm}$ height), the sex-ratio in Takapoto was 0.1 female/ 1 male. The evolution noted over 247 the year of our study was typical of this age group, in which the first inversions of sex are 248 normally known to occur (Thielley 1993). The population raised in the Gambier Islands, 249 therefore, did not differ from populations grown elsewhere in this respect.

\section{Glycogen storage}

Marine bivalves show cycles of energy storage and utilization that are closely related to gametogenic cycles. Most species are able to store nutrient reserves during periods of food abundance. These reserves are mobilized during periods of food depletion and high energy

254 demand (Bayne 1976; Barber and Blake 1981; Heude-Berthelin et al. 2000). During 255 gametogenesis, high-energy demands are made due to maintenance costs and gamete synthesis; these have to be met by the food supply and/or stored reserves. In P. mazatlanica, growing on the west coast of the Gulf of California, glycogen stored in the muscle and digestive gland were actively used for gametogenesis (Saucedo et al. 2002). In $P$. 259 margaritifera, our results show that glycogen obtained from ingested food was mainly stored 260 in the adductor muscle and secondarily in the digestive gland, to be later used for ATP needs and to produce gametes. We studied the relationship between the glycogen storage cycle and 
gametogenesis of the pearl oyster P. margaritifera over the annual cycle (September 2002 to

263 August 2003). Glycogen content increased drastically, showing a 20-fold increase in muscle 264 from February 2003 to May 2003. The energy stored in the muscle could also be used at the 265 time of spawning to achieve vigorous valve movement and to increase the pressure on the 266 gonad to expel the gametes. Our result shows that the maximum glycogen content in the 267 muscle corresponded to the spawning period from March to June. Changes in glycogen 268 content were correlated with temperature in the muscle, mantle and visceral mass (digestive 269 gland and gonad), and with chlorophyll in the visceral mass. Our study confirms that mantle 270 tissue has a negligible role in storage of nutrients during reproduction in P. margaritifera. 271 Few changes were observed in the visceral mass over the study period. The digestive gland 272 considered as a short term storage organ (Saucedo et al. 2002; Vite-Garcia et al. 2008) did not 273 accumulate glycogen over a long period.

\section{Conclusion}

275 The main goal of this work was to examine the hypothesis that the highest thermal amplitude recorded in southern French Polynesia could generate seasonal variation of reproduction in $P$.

277 margaritifera. This study was conducted in the Gambier Islands, where pearl farming is an 278 important industry, and has shown that a seasonal cycle in the reproduction of the pearl 279 oysters does not exist in this area. This study showed that CI (wet weight of gonad/shell 280 weight) could be a good indicator of reproductive events in the pearl oyster. It thus appears

281 that the development of gonads goes on throughout the year in the Gambier Islands, without 282 any detectable phase of sexual rest.

\section{Acknowledgments}

284 This work was supported by logistic and financial aid from the Service de la Perliculture 285 (Grant $\mathrm{N}^{\circ}$ 021435: Reproduction of the black-lip pearl oyster Pinctada margaritifera in the 
Gambier Islands). We also thank Helen McCombie-Boudry for improving the English in this 287 paper.

\section{References}

Bayne BL (1976) Aspects of the reproduction in bivalve mollusks of reproduction. In: M.

290 Wiley, editor. Estuarine Processes, Vol. 1. London, UK: Academic Press. pp. 432-448.

291 Barber BJ, Blake NJ (1981) Energy storage and utilization in relation to gametogenesis in 292 Argopecten irradians concentricus (Say). J Exp Mar Biol Ecol 52: 121-134.

293 Buestel D, Pouvreau S (1994) Ecophysiologie de l'huître perlière. Approche des relations 294 entre la croissance de l'huître Pinctada margaritifera et le milieu dans le lagon de 295 Takapoto. Programme Général de Recherche sur la Nacre. Action de recherche $\mathrm{N}^{\circ} 7$ : 296 Croissance Milieu, 64pp.

297 Buestel D, Pouvreau S (2000) La matière particulaire des eaux du lagon de Takapoto : 298 nourriture potentielle pour les élevages d'huîtres perlières. Oceanologica acta, 23:193-210.

299 Charpy L (1996) Phytoplankton biomass and production in two Tuamotu atoll lagoons 300 (French Polynesia). Mar Ecol Prog Ser 145: 133-142.

301 Charpy L, Bonin P, Boeuf D, Bouvy M, Champalbert G, Claquin P, Dupuy C, Durieux B, 302 Fournier J, Guasco S, Lefebvre S, Michotey V, Orvain F, Pagano M, Thomas Y, Veron B, 303 Lo-Yat A ( 2009) Quality and quantity of available food for pearl oyster: a key parameter 304 for a successful culture. 11th Pacific Science Inter-congress, Tahiti, 2-6 March, 2009. ISBN 305 978-2-11-098964-2.

306 Delesalle B, Sakka A, Legendre L, Pages J, Charpy L, Loret P (2001) The phytoplankton of 307 Takapoto Atoll (Tuamotu Archipelago, French Polynesia): time and space variability of 308 biomass, primary production and composition over 24 years. Aquat Living Resour 14, 175$309 \quad 182$. 
310 Dubois M, Gilles KA, Hamilton JK, Rebers PA, Smith F (1956)

311 Colorimetric method for determination of sugars and related substances $312 \quad$ Anal Chem $28: 350-356$.

313 Garcia-Cuellar JA, Garcia-Dominguez F, Lluch-Belda D, Hernandez-Vasquez S (2004) El

314 Nino and La Nina effects on reproductive cycle of the pearl oyster Pinctada mazatlanica 315 (Hanley, 1856) (Pteriidae) at Isla Espiritu Santo in the Gulf of California. J Shellfish Res $316 \quad 23: 113-120$.

317 Heude Berthelin C, Kellner K, Mathieu M (2000) Storage metabolism in the pacific oyster 318 (Crassostrea gigas) in relation to summer mortalities and reproductive cycle (west coast of 319 France). Comp Biochem Physiol B 125: 359-369.

320 Intes A., Charpy-Roubaud C, Charpy L, Lemasson L, Morize E (1990). "Les lagons d'atoll en 321 Polynésie française: Bilan des travaux du programme "Atoll"." Océanographie-notes et 322 documents $n^{\circ}$ 43: $136 \mathrm{p}$.

323 Maritorena, S., A. Morel, B. Gentili (1994) Diffuse reflectance of oceanic shallow waters: 324 Influence of water depth and bottom albedo. Limnology Oceanography, 39, 1689-1703.

325 McClain CR, Feldman GC, Hooker SB (2004) An overview of the SeaWiFS project and 326 strategies for producing a climate research quality global ocean bio-optical time series. 327 Deep Sea Research Part II, 51, 5-42.

328 O’Connor WA (2002) Latitudinal variation in reproductive behaviour in the pearl oyster, $329 \quad$ Pinctada albina sugillata. Aquaculture 209 :333-345.

330 Pouvreau S (1999) Étude et modélisation des mécanismes impliqués dans la croissance de 331 l'huître perlière, Pinctada margaritifera, au sein de l'écosystème conchylicole du lagon de 332 l'atoll de Takapoto (Polynésie Française). Thèse Univ Rennes. 

cycle and reproductive effort of the tropical blacklip pearl oyster, Pinctada margaritifera (Bivalvia: Pteriidae), cultivated in Takapoto atoll (French Polynesia). Aquat Living Resour 13: $37-48$.

Pouvreau S, Bacher C, Héral M. (2000b) Ecophysiological model of growth and reproduction of the black pearl oyster, Pinctada margaritifera : potential applications for pearl farming in French Polynesia. Aquaculture 186:117-144.

Pouvreau, S., Prasil, V., 2001. Growth of the black-lip pearl oyster, Pinctada margaritifera, at 341 nine culture sites of French Polynesia: synthesis of several sampling designs conducted 342 between 1994 and 1999. Aquat Living Resour 14, 155-163.

Salvat B, A Aubanel, M Adjeroud, P Bouisset, D Calmet, Y Chancerelle, N Cochennec344 Laureau, N Davies, A Fougerousse, R Galzin, E Lagouy, C Lo, C Monier, C Ponsonnet, G 345 Remoissenet, D Schneider, A Stein, M Tatarata, L Villiers (2008). Le suivi de l'état des récifs coralliens de Polynésie française et leur récente évolution. Rev. Écol. (Terre Vie), 63 : 145-177.

Saucedo P, Racotta I, Villarreal H, Monteforte M (2002) Seasonal change in the histological and biochemical profile of the gonad, digestive gland and muscle of the calafia mother-ofpearl oyster, Pinctada mazatlanica (Hanley, 1856) associated with gametogenesis. J Shellfish Res $21: 127-135$.

Thielley M (1993) Etude cytologique de la gamétogenèse, de la sex-ratio et du cycle de reproduction chez l'huître perlière Pinctada margaritifera (L) var cumingii (Jameson), 354 (Mollusques, bivalves). Comparaison avec le cycle de Pinctada maculata (Gould). Thèse Univ. Polynésie Française. 


\section{Figures}
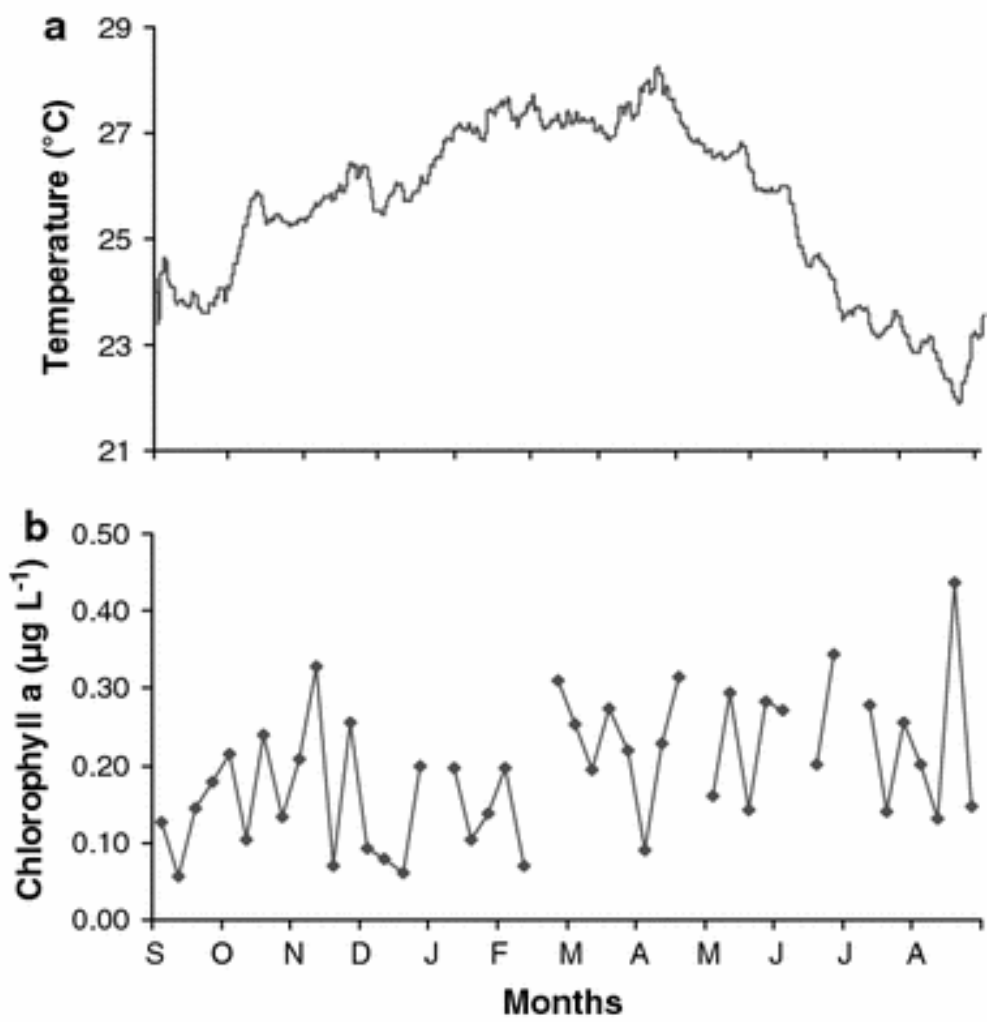

Fig. 1 Variations in temperature (a) and chlorophyll a (b) in 2002-2003 in Gambier Island. Chl a concentrations of Gambier Island ( $\left.134^{\circ} 52^{\prime} \mathrm{W} \& 23^{\circ} 07^{\prime} \mathrm{S}\right)$ were derived from available ocean colour data (SeaWiFS project) 

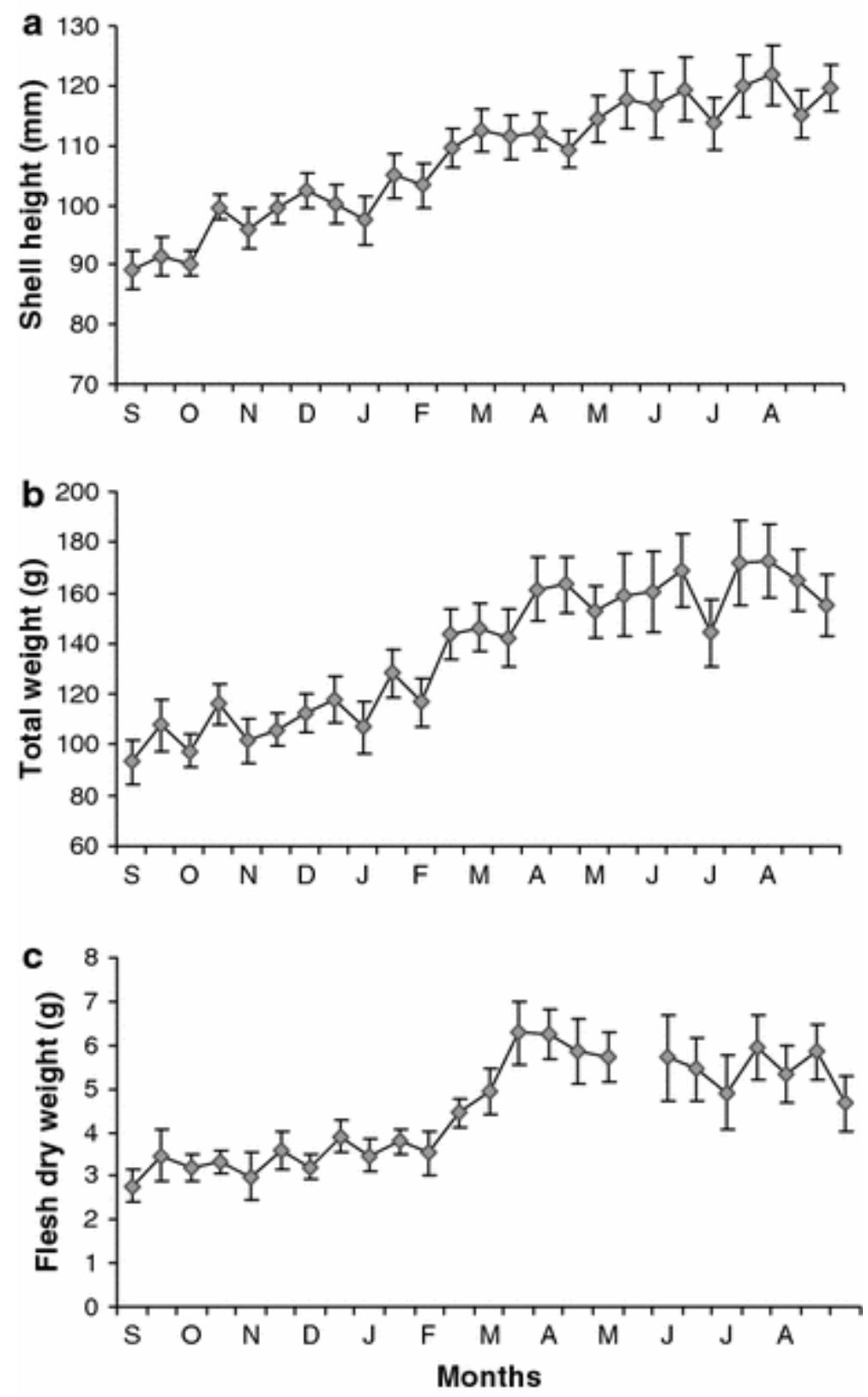

Fig. 2 Shell height (a), total weight (b) and flesh dry weight (c) (mean and confidence interval, $\alpha=5 \%, n=30$ ) in 2002-2003 in Gambier Island 


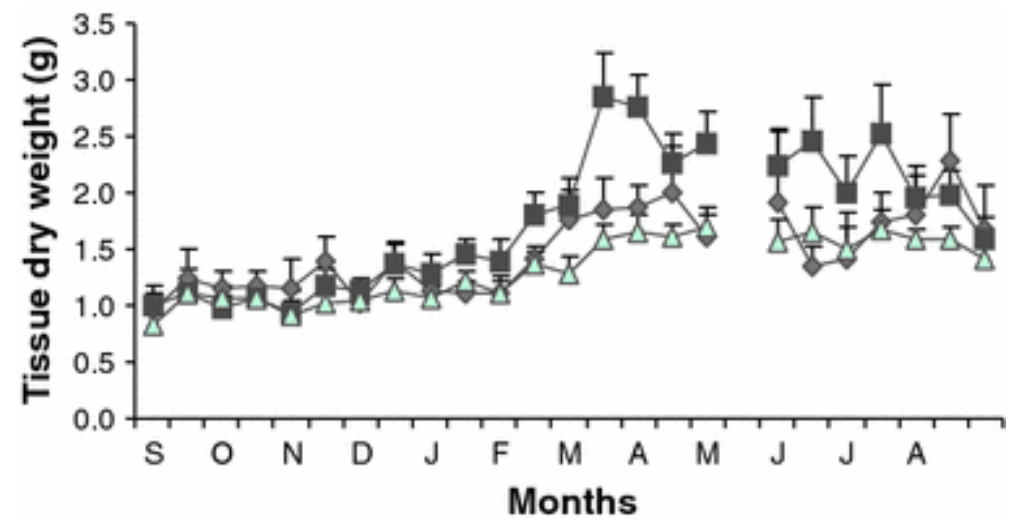

Fig. 3 Tissue dry weight (mean and confidence interval, $\alpha=5 \%, n=15$ ) in 2002-2003 in Gambier Island: muscle (grey circles), visceral mass (black rhombuses) and gill-mantle (grey squares)

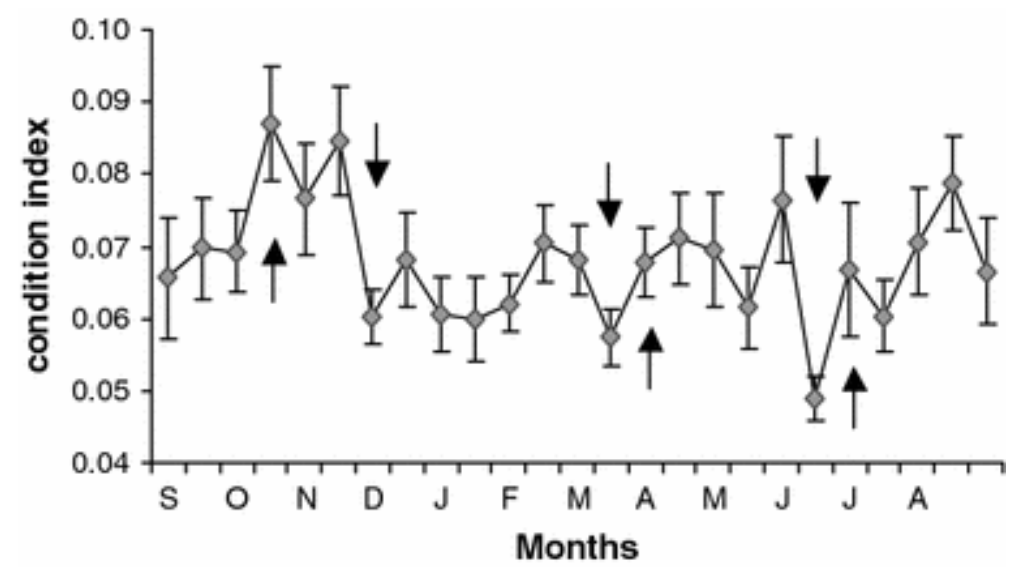

Fig. 4 Condition index (Cl) (mean and confidence interval, $\alpha=5 \%, n=30$ ) in 2002-2003 in Gambier Island $(\mathrm{Cl}=$ visceral mass/shell weight). Arrows indicate significant increase and reduction in conditioning indexes

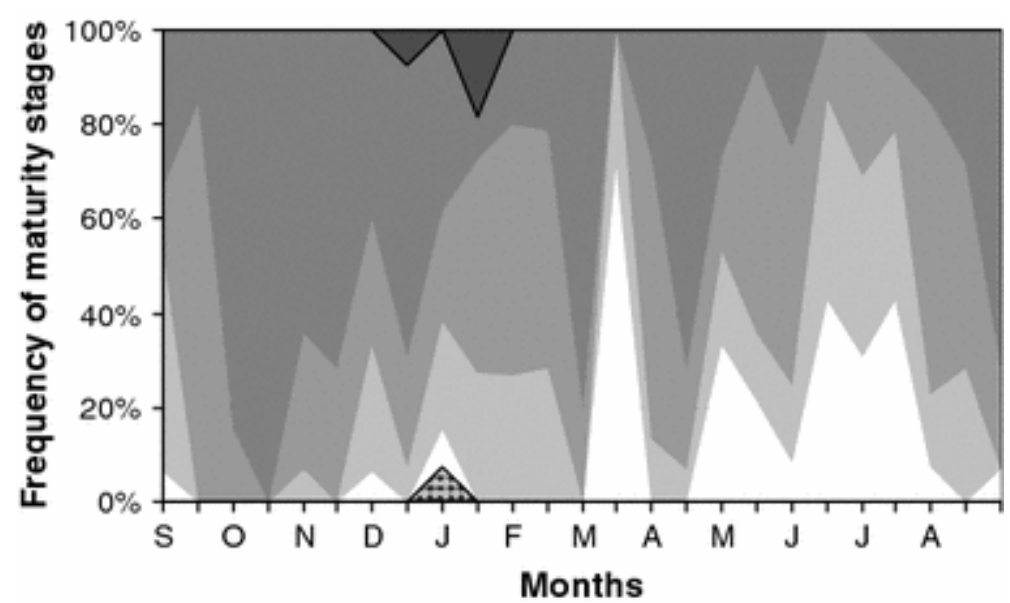

Fig. 5 Histological analysis of the evolution in the frequency of gonadal development stages in 2002-2003 in Gambier Island. Dotted white on black = stage 0 (undetermined or inactive), white = stage 1 (spawning ripe, distended and confluent follicles, entirely filled), clear 
grey = stage 2 (actively developing without mature gametes), mid-grey = stage 3 (near ripe follicles with mature gametes), dark grey = stage 4 (spawning ripe, distended and confluent follicles, entirely filled), black = stage 5 (partially spawned, partially empty lumen), $(n=15)$

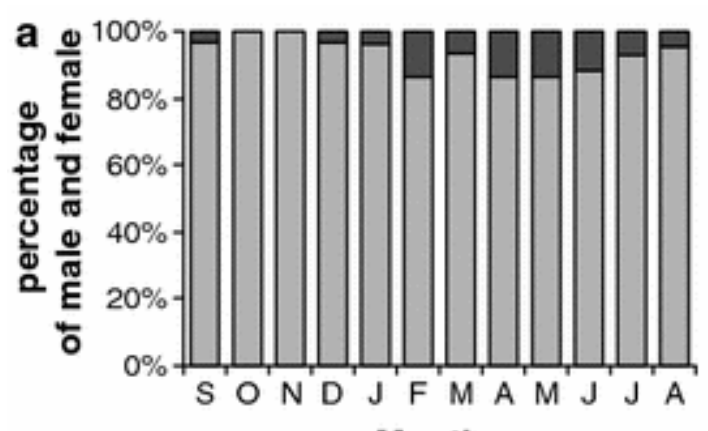

Months

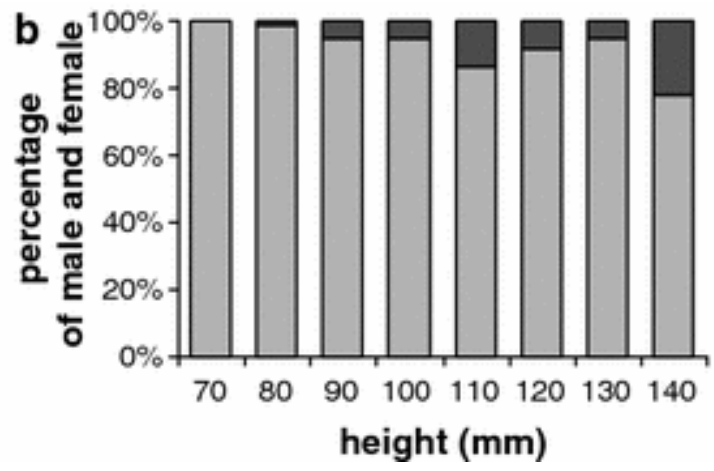

Fig. 6 Sex ratio of $P$. margaritifera in 2002-2003 in Gambier Island (a) and according to shell height $(\mathbf{b})$. Female $=$ black, male $=$ grey $(n=15)$

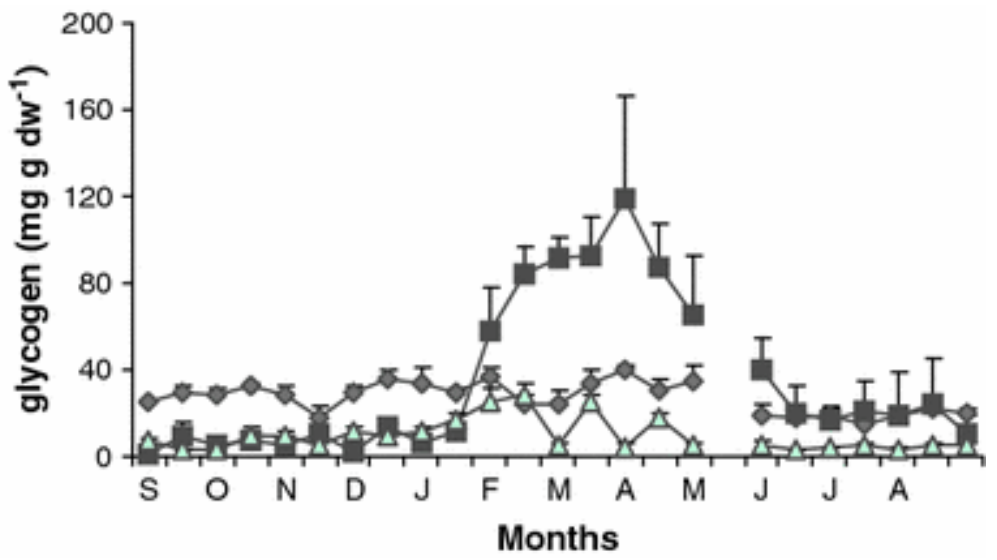

Fig. 7 Glycogen content (mean and confidence interval, $\alpha=5 \%, n=5$ ) in 2002-2003 in Gambier Island: muscle (grey circles), visceral mass (black rhombuses), gill-mantle (dark rhombuses) 


\section{$\underline{\text { Tables }}$}

Table 1 Criteria for histological scoring of gametogenic stages according to Pouvreau et al. (2000a)

\begin{tabular}{|l|l|}
\hline Histological criteria & Score \\
\hline Undetermined or inactive & 0 \\
\hline Early gametogenesis, numerous gonia, small follicles & 1 \\
\hline Actively developing without mature gametes & 2 \\
\hline Near ripe follicles with mature gametes & 3 \\
\hline Spawning ripe, distended and confluent follicles, entirely filled & 4 \\
\hline Partially spawned, partially empty lumen & 5 \\
\hline
\end{tabular}

Table 2 Correlations of chlorophyll a or water temperature (WT) with growth parameters, glycogen content and condition index of Pinctada margaritifera off Gambier Island with Pearson correlation analysis $(N=110, \alpha=0.05)$

\begin{tabular}{|c|c|c|}
\hline & Chlorophyll & Temperature \\
\hline Shell height & 0.433 & -0.159 \\
\hline Total weight & 0.351 & -0.107 \\
\hline Flesh weight & 0.239 & -0.138 \\
\hline \multicolumn{3}{|l|}{ Tissue weight } \\
\hline Visceral mass & 0.215 & -0.098 \\
\hline Add. muscle & 0.306 & 0.023 \\
\hline Gill-mantle & 0.334 & -0.363 \\
\hline \multicolumn{3}{|l|}{ Glycogen } \\
\hline Visceral mass & -0.310 & 0.602 \\
\hline Add. muscle & 0.113 & 0.588 \\
\hline Gill-mantle & -0.267 & 0.623 \\
\hline Condition index & -0.134 & -0.043 \\
\hline
\end{tabular}

The significant correlation values are in bold 